\title{
PEMIKIRAN PENDIDIKAN ISLAM MENURUT HAMKA
}

\author{
Sukari \\ Fakultas Tarbiyah, Institut Islam Mamba’ul ‘Ulum Surakarta \\ e-mail: sukarisolo@gmail.com
}

\begin{abstract}
That the current moral collapse is due to the values of honesty, truth, justice, please help, and compassion have been replaced by misuse, oppression, tackle each other, deception, and mutual harm. So much slander and fighting sheep, licking, corruption, and many other disobedience. The description of social violations occurring in this nation opens space to reflect on the extent to which formal education efforts, which are nationally organized institutions, educate, direct and guide students in a normative way. Because in his view that education is a means of educating personal character. As an Islamic Figure, Hamka's views on Islamic education are very deep. According to Hamka, education is the parents' religious guidance for children by: helping humans to obtain a decent living, but more than that, with human knowledge, they will be able to know their God, refine their morals, and always try to seek the pleasure of God. Therefore, the purpose of education is to serve and worship Him. Therefore, in educational material must include the following three things, namely: science, charity, morals and justice. So we should appreciate Buya Hamka's efforts to participate in developing the intellectual life of the nation by applying its views on education. He founded the $\mathrm{Al}$ Azhar Foundation, which has spread its branches throughout Indonesia.
\end{abstract}

\section{Keywords: Islam, Thought, Education, Hamka}

\section{PENDAHULUAN}

Sesungguhnya pendidikan yang kita laksanakan sekarang ini tidaklah terlepas dari usaha-usaha para tokoh pendidikan dahulu yang telah merintisnya dengan perjuangan yang sangat berat dan tidak mengenal lelah. Oleh karena itu, bila kita berbicara tentang pendidikan yang kini berlangsung tidaklah arif bila tidak membicarakan sosok dan tokoh-tokoh pendidikan tersebut, dengan hanya menerima jerih payah dan karya mereka. Pada dasarnya cukup banyak tokoh pelaku sejarah yang sangat berjasa dalam dunia pendidikan di Indonesia. ${ }^{1}$

Tokoh pendidikan Islam di Indonesia pun sangat banyak, dimana mereka meninggalkan buah perjuangan dan jasa-jasa mereka yang sampai saat ini dinikmati oleh masyarakat Islam di Indonesia terutama dalam hal pendidikan Islam. Namun dalam kesempatan ini hanya satu tokoh yang bisa dikemukakan, dengan tidak mengurangi dan mengecilkan arti perjuangan dan jasa-jasa tokoh lain. Penulis akan memaparkan pemikiran pendidikan menurut Hamka, sebagai seorang tokoh Islam, pandangan Hamka tentang pendidikan Islam sangat mendalam. Menurutnya, pendidikan sebagai sarana yang dapat menunjang dan menimbulkan serta menjadi dasar bagi kemajuan dan kejayaan hidup manusia dalam berbagai ilmu pengetahuan. Pendidikan tersebut tergabung dalam dua prinsip yang saling mendukung, yaitu prinsip keberanian dan kemerdekaan berpikir. ${ }^{2}$

${ }^{1}$ Hasbulah, Dasar-dasar Ilmu Pendidikan, (Jakarta: PT. Raja Grafindo Persada, 2008), Edisi Revisi, h.

${ }^{2}$ Hamka, Falsafah Hidup, (Medan: Pustaka Islamiyah, 1980), h. 208. 


\section{METODE PENELITIAN}

Penelitian ini merupakan penelitian kepustakaan (Library research). Data penelitian ini diambil dari sumber kepustakaan. Penelitian ini menelaah pemikiran seorang tokoh dalam waktu tertentu, maksudnya adalah penelitian berhubungan erat dengan pemikiran yang dituangkan dalam karya atau buku. Penelitian ini mengungkapkan tentang pandangan tokoh mengenai pemikiran pendidikan Islam menurut hamka. Bagaimana seharusnya membangun Pendidikan berdasarkan konsep yang sistematiskan kemudian dihubungkan dengan keadaan atau kondisi suatu benda, tempat, dan keadaan.

\section{PEMBAHASAN}

\section{Pemikiran Pendidikan Islam}

\section{Pengertian Pendidikan Islam}

Ada beberapa istilah bahasa Arab yang mengacu kepada makna pendidikan dalam Islam diantaranya adalah tarbiyah, ta'dib, ta'lim dan tahzib. Dalam hal ini bisa diterjemahkan dengan mendidik sesuai dengan potensi yang ada atau menumbuhkan potensi yang ada yang sesuai dengan fitrah manusia. Adapun Syed Muhammad al-Naquib al-Attas tidak setuju dengan istilah tarbiyah yang menjadi padanan kata pendidikan dalam Islam. Menurutnya ta'dib merupakan istilah yang paling tepat dan cermat bagi konsepsi pendidikan Islam, yang mencakup tarbiyah dan ta 'lim. ${ }^{3}$ Konsep tarbiyah lebih menonjolkan kasih sayang, sedangkan ta'dib lebih menonjolkan pengetahuan ( $\mathrm{ilm}$ ) daripada kasih sayang. Ahmad Fu'ad al-Ahwani menyatakan bahwa dahulu seorang guru disebut dengan mu'addib yang bermakna menjadi teladan, sekarang diistilahkan dengan murabbi. ${ }^{4}$ Tampaknya ada pergeseran istilah dalam hal ini, namun al-Ahwani tidak menyebutkan kapan perubahan itu terjadi, apabila perubahan itu terjadi hanya pada masa modern ini maka sinyalemen al-Attas mungkin ada benarnya. Zakiah Daradjat berpendapat bahwa pendidikan Islam adalah pembentukan kepribadian muslim. ${ }^{5}$ Yūsuf al-Qardhāwiy, berpendapat bahwa pendidikan Islam adalah pendidikan manusia seutuhnya: akal dan hatinya, rohani dan jasmaninya, serta akhlak dan keterampilannya. ${ }^{6}$ Adapun Muhammad 'Athiyah al- Abrāsyi mengemukakan bahwa pendidikan Islam adalah pendidikan akhlak, akan tetapi tidak mengabaikan dalam mempersiapkan hidup seseorang tentang usaha dan rezekinya; karena itu mencakup pula pendidikan jasmani, hati, keterampilan, bahasa, dan lain-lain. ${ }^{7}$

Ahmad Fu'ād al-Ahwāniy berpendapat bahwa pendidikan Islam sejak pada mulanya lahirnya Islam adalah pendidikan agama, akhlak, amal, dan jasmani; tanpa mengabaikan salah satu di antaranya. Hal ini disebabkan karena pendidikan Islam bertujuan untuk mendidik dan membersihkan jiwa, mencerdaskan akal, dan memperkuat jasmani. ${ }^{8}$ Pada

\footnotetext{
${ }^{3}$ Syed Muhammad Naquib al-Attas, Konsep Pendidikan dalam Islam (Bandung: Mizan, 1984), h. 74-75

${ }^{4}$ Ahmad Fu`ad al-Ahwani, Al-Tarbiyah fi al-Islam, Cetakan II (t.tp.: Dar al-Ma'arif, 1967), h. 13

${ }^{5}$ Zakiah Daradjat, dkk., Ilmu Pendidikan Islam, (Jakarta: Proyek Pembinaan Perguruan Tinggi gama/IAIN,1983), h. 27

${ }^{6}$ Yūsuf al-Qardhāwiy, Al-Tarbiyat al-Islāmiyat wa Madrasat Hasan al-Banna, Penerjemah: H. ustami A. Gani dan Zainal Abidin Ahmad, Pendidikan Islam dan Madrasah Hasan al-Banna (Jakarta: Bulan Bintang, 1980), h. 39

${ }^{7}$ Muhammad 'Athiyat al-Abrāsyiy, Al-Tarbiyat al-Islamiyat wa Falāsifatuhā (Mishr:'T̄sā al-Bābiy al-Halabiy, 1975), h. 3.

${ }^{8}$ Ahmad Fu'ād al-Ahwāniy, op. cit., h. 9
} 
umumnya definisi atau pendapat para ahli di atas tidaklah berbeda, walaupun pengungkapan pendapat mereka berbeda-beda. Pada intinya mereka berpendapat bahwa pendidikan Islam itu adalah pendidikan yang didasarkan kepada ajaran Islam yang pada pokoknya bersumber pada Alquran dan hadis Nabi Muhammad SAW, yang akan membawa manusia kepada kebahagiaan dunia dan akhirat.

\section{Tujuan Pendidikan Islam}

Para ahli pendidikan dalam hal ini pendidikan Islam mengkategorikan tujuan pendidikan Islam itu menjadi empat macam, yaitu: tujuan umum, tujuan akhir, tujuan sementara, dan tujuan operasional. ${ }^{9}$

a. Tujuan Umum

Tujuan umum adalah tujuan yang akan dicapai dengan semua kegiatan pendidikan, baik dengan pengajaran atau dengan cara lain. Tujuan umum pendidikan Islam yang akan dicapai dengan semua kegiatan pendidikan Islam mencakup, pembinaan pengetahuan, penghayatan dan keterampilan. Ketiga unsur tersebut biasa dilambangkan dengan: head sebagai lambang pembinaan pengetahuan atau intelektual, heart sebagai lambang pembinaan perasaan, dan hand sebagai lambang pembinaan keterampilan. ${ }^{10}$ Tujuan ilmu pendidikan Islam merupakan kerangka tujuan pendidikan Islam yang selaras dengan tujuan hidup manusia muslim. Oleh sebab itu tujuan ini harus dikaitkan dengan situasi dan kondisi di mana pendidikan Islam itu dilaksanakan. Tujuan yang punya kaitan dengan situasi dan kondisi ini disebut juga dengan tujuan Khusus, misalnya tujuan pendidikan Islam di Indonesia harus dikaitkan dengan falsafah hidup bangsa Indonesia Pancasila serta Undang-Undang Dasar 1945 dan Garis-garis Besar Haluan Negara. Insan Kamil dengan pola taqwa yang merupakan tujuan umum pendidikan Islam bisa dijabarkan pada setiap tingkat umur, kecerdasan, situasi, dan kondisi.

Meskipun bobot tujuan umum berbeda namun tetap mempunyai kerangka yang sama. Tujuan pendidikan Islam di tingkat anak-anak misalnya punya kerangka yang sama dengan tujuan pendidikan Islam di tingkat remaja namun punya bobot yang berbeda. Jika dihubungkan dengan pendidikan formal baik sekolah atau madrasah, maka tujuan tersebut di atas disebut dengan tujuan kurikuler yang selanjutnya dikembangkan dalam tujuan instruksional.

b. Tujuan Akhir

Pendidikan Islam, sebagaimana kita ketahui berlangsung seumur hidup, prosesnya tidak akan berakhir kecuali seseorang meninggal dunia. Islam menganggap bahwa saatsaat terakhir inilah yang menentukan apakah seseorang itu berhasil mencapai tujuan atau tidak; apakah ia mencapai tujuan atau tidak. Apabila seseorang berhasil mencapai husnul khatimah pada akhir hayatnya berarti dia berhasil mencapai tujuan akhir pendidikan Islam.

Mati dalam keadaan berserah diri kepada Allah sebagai muslim yang merupakan ujung dari taqwa sebagai akhir dari proses hidup, dan inilah tujuan akhir pendidikan Islam.

\footnotetext{
${ }^{9}$ Zakiah Daradjat, op. cit., h. $29-32$.

${ }^{10}$ Sofyani, Ilmu Pendidikan Islam, (Banjarmasin: Fakultas Tarbiyah IAIN Antasari, 1987), h.23.
} 
c. Tujuan Sementara

Dalam rangka mencapai tujuan akhir diperlukan sekali untuk merumuskan tujuan sementara, yang merupakan tahapan dalam mencapai tujuan akhir. Tujuan sementara ialah tujuan yang akan dicapai setelah anak diberi sejumlah pengalaman tertentu yang direncanakan dalam suatu kurikulum pendidikan formal. Tujuan pendidikan Islam seolaholah merupakan suatu lingkaran, pada tingkat pendidikan yang paling rendah mungkin merupakan suatu lingkaran kecil, semakin tinggi tingkatan pendidikannya semakin tinggi pula lingkarannya. Tetapi sejak dari tujuan pendidikan tingkat permulaan atau rendah, bentuk lingkarannya sudah harus kelihatan dan bentuk Insan Kamil sebagai tujuan umum dan akhir pendidikan Islam sudah tergambarkan. Jadi meskipun polanya sama namun bobot dan mutu pendidikan Islam tentunya berbeda antara tingkat MI, MTs, MA dan PT. Dalam pendidikan formal, tujuan sementara ini merupakan tujuan yang akan dicapai anak didik setelah diberikan sejumlah pengalaman atau pengetahuan tertentu. Tujuan sementara ini merupakan tingkatan-tingkatan yang dilalui dalam mencapai tujuan akhir.

d. Tujuan Operasional

Untuk mendukung tercapainya tujuan sementara diperlukan adanya tujuan operasional. Tujuan ini bersifat praktis yaitu berupa kemampuan dan keterampilan yang harus dikuasai oleh anak didik meskipun tidak menyentuh penghayatan yang mendalam. Biasanya tujuan ini dirumuskan dalam tujuan instruksional. Dalam pendidikan formal terutama dalam pembuatan persiapan mengajar dalam setiap mata pelajaran biasanya tujuan ini dikembangkan menjadi tujuan Instruksional umum (TIU) dan tujuan instruksional khusus (TIK). Tujuan instruksional khusus merupakan penjabaran dari tujuan instruksional umum yang direncanakan dalam unit- unit kegiatan pengajaran. Sekarang istilah instruksional diganti dengan istilah pembelajaran. Dalam proses pendidikan tujuan operasional ini berkaitan dengan kegiatan lahiriah, seperti bacaan dan kaifiat serta tingkah laku. Pada tahap permulaan bagi anak yang penting adalah mampu dan terampil berbuat atau mengucapkan sesuatu yang baru kemudian menghayati atau memahaminya.

\section{Riwayat Hidup Hamka}

Nama lengkap Hamka adalah Haji Abdul Malik Karim Amrullah bin Amrullah bin Shalih. Merupakan seorang tokoh sufi yang dilahirkan Tanah Sirah di Tepian Danau Sungai Batang Maninjau pada hari Ahad petang, malam Senin tanggal 13 masuk 14 Muharram 1326 $\mathrm{H}$ atau tanggal 16 Pebruari $1908 \mathrm{M} .{ }^{11}$ Hamka merupakan putra pertama pasangan Haji Abdul Karim Amrullah (Haji Rasul) dengan seorang wanita bernama Shafiyah. Ayahnya yang merupakan seorang tokoh gerakan pembaharu kaum muda di Tanah Minang yang gencar menentang paham-paham dari kaum tua khususnya ajaran Rabithah. Pada usia 7 tahun Hamka masuk sekolah dasar dan malamnya belajar mengaji al-Qur'an dengan ayahnya sendiri sampai khatam. Dari tahun 1916 -1923 ia belajar agama pada sekolah "Diniyah School" dan "Sumatera Thawalib" di Padang Panjang dan di Parabek. Gurunya waktu itu ialah Syekh Ibrahim Musa Parabek, Engku Mudo Abdul Hamid dan Zainuddin Labay. ${ }^{12}$

\footnotetext{
${ }^{11}$ Hamka, Doktrin Islam yang Menimbulkan Kemedekaan dan Keberanian, (Jakarta: Yayasan Idatu, 1975).

${ }^{12}$ Hamka, Kenang-kenangan Hidup, (Jakarta: Bulan Bintang, 1979), Jilid I, h. 69
} 
Pada akhir 1924 (berusia 16 tahun) Hamka berangkat ke tanah Jawa dan langsung ke Yogyakarta, kemudian belajar pergerakan Islam modern kepada H.O.S. Cokrominoto, R.M. Soejopronoto dan H. Fakhruddin, yang mengadakan kursus- kursus pergerakan di gedung Abdi Dharmo di Pakualaman Yogyakarta, sehingga mengenal perbandingan antara pergerakan politik Islam, yaitu Syarikat Islam, HindiaTimur dan gerakan sosial Muhammadiyah. ${ }^{13}$ Ia kemudian berangkat menuju Pekalongan, menemui gurunya dan suami kakaknya A.R. Sutan Mansur, yang menjadi ketua (Voerzitter) Muhammadiyah cabang Pekalongan. Disana ia berkenalan dengan Citrosuarno, Mas Usman Pujotomo. Pada tahun 1925 barulah ia kembali ke kampung halamannya, yaitu Padang Panjang dan mendirikan Tablig Muhammadiyah. ${ }^{14}$

Aktivitasnya yang kian hari kian semakin bersemangat, ternyata tidak sepenuhnya mendapat respon yang positif dari masyarakat luas, bahkan banyak mendapatkan cemoohan, sindiran dan lain sebagainya dari masyarakat dan dari mulut ayahnya sendiri yang beranggapan bahwa ia hanya bisa berpidato dan bercerita. Banyak pula orang menganggap bahwa ia mempunyai sisi kelemahan dalam penguasaan bahasa Arab, sehingga ia merasa terpanggil untuk menjawab tantangan itu dan bertekad harus membuktikan dirinya.

Pada bulan Pebruari 1927 Hamka memutuskan pergi ke Mekkah untuk berkelana dan belajar agama di sana. Selama ia berada di Mekkah ia bekerja pada sebuah percetakan kurang lebih selama 6 bulan dan pada bulan Juni 1927 ia pulang ke Medan. Dengan pengalamannya tersebut, walaupun tidak begitu banyak belajar agama secara intensif dengan guru disana, iapun kemudian membuat tulisan tentang pengalamannya selama di Mekkah dan ditawarkan kepada redaktur surat kabar "Pelita Andalas" Medan, dan diterima sekaligus merupakan momen awal dikenalnya Hamka muda sebagai seorang pengarang. ${ }^{15}$ Beberapa lama di Medan, iapun pulang kekampungnya dan berjumpa dengan ayahnya setelah hampir sepuluh tahun beliau tidak bertemu.

Ayahnya menjodohkannya dengan seorang wanita yang bernama Siti Rohmah, dan dinikahinya pada tanggal 5 April 1929. Setelah menikah, ia juga sibuk mengurusi Cabang Muhammadiyah dan Tablig School di Padang Panjang. ${ }^{16}$ Hamka kemudian diutus cabang Muhammadiyah Padang Panjang yang didirikan Muhammadiyah di Bengkalis, dan langsung menghadiri kongres Muhammadiyah ke-20 di Yogyakarta. Pada tahun 1931 diutus oleh Pengurus Besar Muhammadiyah Yogyakarta ke Makasar untuk menjadi Muballig Muhammadiyah dalam tugas khusus menggerakkan semangat menyambut kongres Muhammadiyah ke-21 di Makasar, kemudian tahun 1933 ia menghadiri kongres Muhammadiyah di Semarang. ${ }^{17}$ Antara tahun 1930-1942 kegiatannya banyak disibukkan dengan aktivitas tulis menulis, dan banyak karya-karyanya yang beredar di masyarakat luas, dan banyak membuat tulisan dalam bentuk artikel-artikel yang dimuat di majalah bulanan Muhammadiyah. ${ }^{18}$

\footnotetext{
${ }^{13}$ Mohammad Damami, Tasawuf Positif, (Dalam Pemikiran Hamka), (Yogyakarta: Fajar Pustaka, 2000), Cet I, h. 35.

${ }^{14}$ Mohammad Damami, Tasawuf Positif, (Dalam Pemikiran Hamka), (Yogyakarta: Fajar Pustaka, 2000), Cet I, h. 35.

${ }^{15}$ Rusydi, Pribadi dan Martabat Buya Hamka, (Jakarta: Pustaka Panji Mas, 1983), Cet III, h.2.

${ }^{16}$ Hamka, Kenang-kenangan Hidup, (Jakarta: Bulan Bintang, 1983), Jilid II, h. 20-22.

${ }^{17}$ Rusydi, Pribadi dan Martabat Buya Hamka, (Jakarta: Pustaka Panji Mas, 1983), Cet III, h.3.

${ }^{18}$ Hamka, Kenang-kenangan Hidup, (Jakarta: Bulan Bintang, 1983), Jilid II, h. 96.
} 
Setelah habis kewajibannya menjadi utusan Pengurus Besar Muhammadiyah di Makasar, Ambon dan Manado tahun 1934, dikelilinginyalah pulau Bali dan Jawa. Pada tahun 1935 ia mendirikan sebuah sekolah menengah Islam di Padang Panjang yang diberi nama "Kulliyatul Muballighin", yang mencetak muballig-muballig Islam. ${ }^{19}$ Menjelang akhir tahun 1935, Hamka memegang jabatan sebagai ketua redaksi sebuah majalah mingguan yang bernama "Pedoman Masyarakat" di bawah pimpinan H. Asbiran Ya'kub. Aktivitas mengarangnya terus ditingkatkannya sejak mulai bekerja pada tanggal 22 Januari 1936 sampai berhenti terbit karena masuknya pasukan Jepang pada tanggal 13 Maret 1942. Di tahun 1942 merupakan tahun kejatuhan Hindia Belanda ditangan kekuasan Dai Nippon, dan Hamka diberikan kepercayaan oleh Letnan T. Nakashima untuk menjadi penasehat Gubernur (Tyokan) dikawasan Sumatra Timur. ${ }^{20}$ Kedekatannya tersebut menimbulkan anggapan miring, dan sempat dituduh sebagai penjilat karena berkolaborasi dengan pihak Jepang, meskipun ia terus melancarkan kegiatan tablig. $^{21}$

Pada waktu itu Hamka ternyata terus berupaya mengumandangkan semangat berjuang sehingga perjuangan ini menghasilkan Komisi Tiga Negara (KTN) yang nama anggotanya terdiri dari Amerika Serikat, Australia dan Belgia. Selain itu, dengan kesuksesan merangkul para tokoh politik, pemerintah dan kelaskaran akhirnya pada tanggal 14 Agustus berdirilah Front Pertahanan Nasional (FTN) di bawah pimpinan Hamka. ${ }^{22}$ Pada tahun 1950, Hamka hijrah dengan seluruh keluarganya, dan rumah kediaman beliau di Gang Toa Hong II/141. Kemudian menunaikan ibadah haji yang kedua, dan melanjutkan perjalanannya dengan berkeliling ke negara-negara Timur Tengah, dan bertemu beberapa tokoh terkemuka antara lain yaitu Dr. Thaha Huseindan Mufti Palestina Amin al-Husaini.

Pada tahun 1958 ia sekali lagi ke Mesir dan menerima Doktor Honoris Causa dari Universitas al-Azhar, dan menerima hal serupa pada tahun 1976 dari universitas kebangsaan Malaysia. ${ }^{23}$ Selain aktif di organisasi Muhammadiyah, ia juga aktif di partai politik Masyumi, sehingga dimasukkan penjara dari tahun 1964-1966 di masa rezim Soekarno. Setelah keluar penjara ia tidak aktif lagi dalam politik dan mulai dengan kegiatan-kegiatan di bidang dakwah dan menjadi imam besar Mesjid Agung Al-Azhar Jakarta. Mulai tahun 1975 s/d 1980 Hamka menjabat ketua umum Majelis Ulama Indonesia (MUI). ${ }^{24}$ Pada hari tuanya Hamka tetap berkhidmat dengan berbagai aktivitas seperti menulis, mengumandangkan kalimat tablig dan lain sebagainya, sehingga mendapat gelar "Penyambung Suara Rakyat". ${ }^{25}$ Sosoknyapun menjelma keseluruh bidang dalam disiplin keilmuan. merasuk ke dalam dunia sastrawan, berperan sebagai ulama, wartawan, filosof, pujangga dan sekaligus pimpinan pergerakan Muhammadiyah. Beliau berpulang ke-rahmatullah tepat pada tanggal 24 Juli 1980, hari Jum'at pukul 10.41 di usia 73 tahun lima bulan, dengan meninggalkan 10 orang anak, 9 menantu dan 22 cucu, dan dimakamkan di pemakaman umum tanah Kusir Jakarta. ${ }^{26}$

\footnotetext{
${ }^{19}$ Hamka, Kenang-kenangan Hidup, (Jakarta: Bulan Bintang, 1983), Jilid II, h. 96

${ }^{20}$ Yayasan Nurul Islam, Kenang-Kenangan 70 tahun Buya Hamka, (Jakarta, 1978), Cet I, h.107.

${ }^{21}$ Hamka, Kenang-kenangan Hidup, (Kuala Lumpur: Pustaka Antara, 1982), Jilid III, Cet II,h. 296.

${ }^{22}$ Yayasan Nurul Islam, Kenang-Kenangan 70 tahun Buya Hamka, (Jakarta, 1978), Cet I, h.84.

${ }^{23}$ Yayasan Nurul Islam, Kenang-Kenangan 70 tahun Buya Hamka, (Jakarta, 1978), Cet I, h.96.

${ }^{24}$ Laily Mansur, Ajaran dan Teladan Para Sufi, (Jakarta: Raja Grafindo Persada, 1996), Cet ke-I, h.

${ }^{25}$ Panji Mas, Perjalanan Terakhir Buya Hamka, (Jakarta: CV. Restu Ibu, 1982), Cet ke-II, h.48.

${ }^{26}$ Rusydi, Pribadi dan Martabat Buya Hamka, (Jakarta: Pustaka Panji Mas, 1983), Cet III, h. 117.
} 324-325. 


\section{Karya-Karya Hamka}

Dalam kehidupan Hamka, menulis merupakan karir yang sangat menonjol, tidak sedikit karangan-karangannya menghiasi sekaligus mengisi kehidupan masyarakat. Secara garis besar karangan-karangannya berkisar mengenai masalah agama, filsafat, budaya, sejarah dan sastra, yang di tulis semenjak berusia 17 tahun hingga menjelang akhir hayatnya (dari tahun 1925 sampai tahun 1975).

Karya-karya kepengarangannya pada tahun 1925-1935 yaitu: Khatibul Ummah, yang terdiri dari 3 jilid. Merupakan kitab yang dicetak dengan huruf Arab, yang jadi momen awal kiprahnya sebagai penulis, Pembela Islam (Tarikh Sayyidina Abu Bakar), tahun 1929, Adat Minangkabau dan Agama Islam, tahun 1929, Ringkasan Tarikh Umat Islam (berisikan sejarah Nabi Muhammad Saw, sejarah Khalifah Empat, Bani Abbasiyah dan Bani Umayyah), tahun 1929 Majalah Kemauan Zaman, tahun 1925, Kepentingan Melakukan Tablig, tahun 1929, Hikmah Isra' dan Mi'raj, Arkanul Islam, tahun 1932, Majalah Tentara (4 nomor), Makasar tahun 1932, Majalah al-Mahadi (9 nomor), Makasar, tahun 1932, dan Mati Mengandung Malu, Tahun 1934.,Selain karya-karya yang tersebut di atas masih banyak lagi karya dan tulisannya yang berbentuk sajak-sajak, cerita-cerita perjalanan serta berbagai tema dalam surat kabar dan majalah-majalah. Adapun hasil karya yang dihasilkan beliau dari tahun 1935 sampai tahun 1942 yaitu sebagai berikut: Di bawah Lindungan Ka'bah; Balai Pustaka, 1936, Tenggelamnya Kapal Van Der Wijck; Balai Pustaka, 1937, Di Dalam Lembah kehidupan; Balai Pustaka, 1939, dan Merantau Ke Deli. Keempat karangan Hamka tersebut dalam bentuk roman, yang memiliki isi dan gaya bahasa yang tinggi. Para pembaca karyakaryanya pada umumnya sangat terpukau oleh corak gaya bahasa yang ditampilkannya. Karya-karya itu banyak dipengaruhi oleh sastrawan Mesir Musthafa Luthfi al-Manfaluthi, yaitu: Margaretta Gauthie (terjemahan) (1940), Tuan Diretur (1939), Dijemput Mamaknya (1939), Keadilan Ilahi (1939), Tasawuf Modern (1939), Falsafah Hidup (1939), Lembaga Hidup (1940),31 Lembaga Budi (1940), Agama dan Perempuan (1939), dan Pedoman Muballig Islam (1937).

Buku novel yang ditulis atau terjemahkan menjadi buah bibir di kalangan pemuda pemudi pada masa itu. Bahkan menjadi kritik tajam bagi sebagian para ulama tradisional. "Haji atau ulama roman?", begitu kritik yang ditujukan kepadanya. Karena para ulama tradisional pada saat itu kurang dapat menerima jika seorang ulama menulis tentang percintaan dan roman. ${ }^{27}$ Adapun salah satu karya terbesar lainnya adalah Tafsir Alquran Al Azhar. Tafsir ini merupakan satu karya monumental yang memperlihatkan kedalaman ilmunya dalam bidang tafsir. Buku ini terdiri dari 30 jilid yang ditulis pada tahun 1966, saat beliau berada dalam tahanan pada masa pemerintahan Soekarno. ${ }^{28}$

\section{Pemikiran Pendidikan Islam Menurut Hamka}

Hamka mengemukakan pemikirannya tentang pendidikan, bahwa pendidikan sebagai sarana yang dapat menunjang dan menimbulkan serta menjadi dasar bagi kemajuan dan

\footnotetext{
${ }^{27}$ Alvia Harafit Lasmar'ati, Abdul Malik bin Abdul Karim Amrullah Ulama Sekaligus Sastrawan Besar, 15Juli 2006 dalam http://riwayat-hamka.blogspot.com/ diunduh tanggal 13 Junin 2021.

${ }^{28}$ A. Susanto, Pemikiran Pendidikan Islam, (Jakarta: Amzah, 2009), Cet. I, h. 105.
} 
kejayaan hidup manusia dalam berbagai ilmu pengetahuan. ${ }^{29}$ Selanjutnya beberapa pemikiran Hamka tentang pentingnya pendidikan Islam:

\section{Urgensi Pendidikan}

Mengenai urgensi pendidikan, Hamka mengemukakan pemikirannya tentang pentingnya manusia mencari ilmu pengetahuan, sebab bukan hanya untuk membantu manusia memperoleh penghidupan yang layak, tetapi lebih dari itu, dengan ilmu manusia akan mampu mengenal tuhannya, memperhalus akhlaknya, dan senantiasa berupaya mencari keridhaan Allah. Hanya dengan bentuk pendidikan yang demikian, manusia akan memperoleh ketentraman (hikmat) dalam hidupnya. ${ }^{30}$ Dalam pandangan Hamka pendidikan sebenarnya terbagi kepada dua bagian:

Pertama, pendidikan jasmani, yaitu pendidikan untuk pertumbuhan dan kesempurnaan jasmani serta kekuatan jiwa dan akal. Dengan memahami pentingnya pendidikan tubuh atau badan, seperti berolah raga teratur, istirahat yang cukup dan bekerja, maka tubuh akan sehat dan jauh dari sakit. Kedua, pendidikan ruhani, yaitu pendidikan untuk kesempurnaan fitrah manusia dengan ilmu pengetahuan dan pengalamannya yang didasarkan kepada agama. Maksudnya ialah jiwa atau ruhani harus diberikan siraman pendidikan agama, beribadah, bersikap dan berakhlak baik. Dalam kitabnya ini amka melakukan pembahasan tafsirnya dengan menggunakan pendekatan ilmiah, keilmuan, filsafat, susastraan, hukum, sejarah, budaya, sosial kemasyarakatan, tasawuf, hadis, menafsirkan al-Quran dengan alQuran. Selain itu di dalam tafsirnya Hamka juga sering memaparkan pendapat-pendapat para mufassir sebelumnya, untuk memperkuat gagasan-gagasannya, namun tak jarang ia menampilkan pula pendapat-pendapat yang bertentangan, di sinilah kita melihat kepiawaian Hamka dalam meracik tafsirnya, Ketika ada perdebatan-perdebatan yang tajam dan berlarutberlarut, ia berusaha mengkompromikan berbagai pandangan yang paradoks tersebut.

Kedua unsur jasmani dan ruhani tersebut memiliki kecenderungan untuk berkembang, dan untuk menumbuhkembangkan keduanya adalah melalui pendidikan karena pendidikan merupakan sarana yang paling tepat dalam menentukan perkembangan secara optimal kedua unsur tersebut. Dalam pandangan Islam, kedua unsur tersebut dikenal dengan istilah fitrah. Artinya, setiap manusia pada dasarnya menuntun untuk senantiasa berbuat kebajikan dan untuk mengabdi kepada khaliqnya. ${ }^{31}$ Jika ada manusia yang tidak berbuat kebajikan, maka sesungguhnya ia telah menyimpang dari fitrahnya tersebut. Menurutnya, pada diri setiap anak (manusia), terdapat tiga unsur utama yang dapat menopang tugasnya sebagai khalifah fil ardh maupun 'abdullah. ${ }^{32}$ Selain itu, menurut Hamka bahwa fitrah manusia yang berjalan seirama dengan hukum-hukum Allah akan menemui dirinya sendiri yang awalnya tercipta dalam keadaan suci tanpa dosa. ${ }^{33}$ Dengan perpaduan tiga unsur, yaitu akal, hati dan pancaindra yang terdapat pada jasad manusia, maka membantu manusia untuk memperoleh ilmu pengetahuan dan membangun peradaban, memahami fungsi kekhalifahannya, serta menangkap tandatanda kebesaran Allah. ${ }^{34}$

\footnotetext{
${ }^{29}$ Hamka, Lembaga Hidup, (Jakarta: Djajamurni, 1972), h. 54.

${ }^{30}$ Armai Arief, Reformulasi Pendidikan Islam, (Jakarta: CRSD Press, 2009), h.178-179.

${ }^{31}$ Hamka, Falsafah Hidup, (Medan: Pustaka Islamiyah, 1980), h. 66.

${ }^{32}$ A. Susanto, Pemikiran Pendidikan Islam, (Jakarta: Amzah, 2009), Cet. I, h. 106.

${ }^{33}$ Beni Ahmad Saebani dan Hendra Akhdiyat, Ilmu Pendidikan Islam, Jilid 1, (Bandung: Pustaka Setia, 2009), h. 53.

${ }^{34}$ A. Susanto, Pemikiran Pendidikan Islam, (Jakarta: Amzah, 2009), Cet. I, h. 99.
} 


\section{Pengertian dan Tujuan Pendidikan}

Lebih lanjut mengenai pendidikan, maka Hamka membedakan tentang makna pendidikan dan pengajaran. Menurutnya, pendidikan adalah "serangkaian upaya yang dilakukan pendidik untuk membantu membentuk watak, budi, akhlak, dan kepribadian peserta didik. ${ }^{35}$ Sementara pengajaran adalah "upaya untuk mengisi intelektual peserta didik dengan sejumlah ilmu pengetahuan. Perbedaan kedua pengertian tersebut menurutnya sebetulnya hanya pada maknanya saja, namun secara esensi ia tidak membedakannya. Kedua kata tersebut memuat makna yang tak terpisahkan dan saling melengkapi dalam rangka mencapai tujuan yang sama. Saling melengkapi dalam rangka mencapai tujuan yang sama. Sebab, setiap proses pendidikan didalamnya terdapat proses pengajaran. Tujuan dan misi pendidikan akan tercapai melalui proses pengajaran. Demikian pula sebaliknya, proses pengajaran tidak akan banyak berarti apabila tidak dibarengi dengan proses pendidikan. ${ }^{36}$

Adapun tujuan pendidikan menurut Hamka adalah memiliki dua dimensi; bahagia di dunia dan di akhirat. Untuk mencapai tujuan tersebut, manusia harus menjalankan tugasnya dengan baik, yaitu beribadah. Oleh karena itu, segala proses pendidikan pada akhirnya bertujuan agar dapat menuju dan menjadikan anak didik sebagai abdi Allah. ${ }^{37}$ Mengenai tujuan akhir pendidikan ini, kemudian Hamka mengemukakan firman Allah surah AdzDzariyaat ayat 56. Dalam menafsirkan ayat tersebut, Hamka mengemukakan bahwa ayat tersebut sangat relefan sekali dengan tujuan pendidikan Islam adalah sama dengan tujuan penciptaan manusia itu sendiri, yaitu untuk mengabdi dan beribadah kepada Allah. Ia mengatakan bahwa ibadah adalah "mengakui diri sebagai budak atau hamba Allah, tunduk kepada kemauannya, baik secara suka rela maupun terpaksa". 38

3. Materi Pendidikan

Mengenai materi pendidikan, dalam pandangan Hamka pada dasarnya berkisar antara ilmu, amal, akal dan keadilan. Ketiga konsep tersebut sangat mendasari proses pendidikan tersebut. Pertama, ilmu. Menurut Hamka ilmu terbagi dua macam, yaitu ilmu yang bersumber dari wahyu yang mutlak kebenarannya, yang disebut dengan al-'ulum annaqliyah, dan ilmu yang bersumber dari akal manusia yang relatif kebenarannya, biasanya disebut dengan al- 'ulum al- 'aqliyah. ${ }^{39}$ Ilmu yang pertama mencakup segala ruang dan dimensi waktu yang meliputi suatu yang gaib (tidak tampak) dan yang tampak. Ilmu kedua hanya mencakup sebagian kecil dari gejala-gejala alam yang bersifat nyata dan tidak menembus perkara yang gaib, sekalipun ia seorang Nabi. Adapun ilmu yang pertama diperoleh melalui kebenaran wahyu yang dipindahkan dari generasi ke generasi berikutnya. Ilmu kedua dapat diperoleh melalui kecerdasan akal pada tahap intelek dan rasio. Menurutnya, ilmu manusia tidak dapat menandingi ilmu Allah, sehingga selayaknya manusia menyadari bahwa ilmunya tidak seberapa jika dibandingkan dengan ilmu Allah.

Kedua, amal dan akhlak. Ilmu yang hanya dibarengi dengan iman tidaklah cukup, namun harus pula dibarengi dengan amal, kerja dan usaha. Ilmu yang tidak diikuti dengan amal perbuatan baik tidak berguna bagi kehidupan. Ilmu yang baik, seharusnya bisa

\footnotetext{
${ }^{35}$ Hamka, Lembaga Hidup, (Jakarta: Djajamurni, 1972), h. 202.

${ }^{36}$ A. Susanto, Pemikiran Pendidikan Islam, (Jakarta: Amzah, 2009), Cet. I, h. 107.

${ }^{37}$ Hamka, Falsafah Hidup, (Medan: Pustaka Islamiyah, 1980), h. 66.

${ }^{38}$ Hamka, Tafsir Al-Azhar, (Jakarta: Pustaka Panjimas, 1998), Juz. 27, h. 37

${ }^{39}$ Hamka, Pelajaran Agama Islam, (Jakarta: Bulan Bintang, 1984), h. 84.
} 
membekas ke luar diri individu dan orang lain. Ilmu pengetahuan harus diamalkan dan agama Islam adalah agama ilmu dan sekaligus amal. Hubungan antara iman dengan amal, adalah hubungan antara budi dan perangai. Jadi, berbudi dan bergaul yang baik termasuk amal. ${ }^{40}$

Materi sebagaimana ditafsirkan Hamka pada surah Luqman ayat 14-15. Menurutnya, maksud kedua ayat (14-15) tersebut adalah berkaitan perintah dari Allah kepada manusia agar menghormati dan memuliakan kepada kedua ibu bapaknya Melalui keduanyalah manusia dilahirkan ke muka bumi, sewajarnyalah jika keduanya dihormati. Juga harus menghormati ibu yang telah mengandung dalam berpayah-payah sampai puncak kepayahan saat melahirkan. Kemudian mengasuh anak sampai dua tahun. Oleh karena itu, bersyukurlah kepada Allah yang telah menciptakan manusia, dan kemudian bersyukurlah kepada kedua orang tuamu. Pentingnya hal ini karena anak itu, kemudian juga akan berumah tangga, dan akan merasakan pula menjadi orang tua. Untuk semuanya akhirnya kembali kepada Tuhan. Namun jika kedua orang tua mengajak untuk menukar tauhid anak, maka "janganlah engkau ikuti keduanya". Meskipun demikian, keduanya harus tetap dihormati, disayangi, dicintai dengan sepatutnya, dengan cara yang ma'ruf. Jangan mereka dicaci dan dihina. Kala mereka sudah tua, asuh jugalah mereka dengan baik. Tunjukkanlah bahwa seorang Muslim adalah seorang budiman tulen! $!^{41}$

Ketiga, keadilan. Defenisi keadilan adalah 'tegak di tengah'. Jelasnya keadilan adalah sebagai pertahanan yang memikat hati dan menyebabkan orang takluk dan patuh dengan segala kerendahan hati. Dalam konsep keadilan ini terkandung unsur persamaan, kemerdekaan dan kepemilikan. Persamaan adalah hak segenap manusia. ${ }^{42}$ Oleh karena itu, dalam hal keadilan ini haruslah tegak amar ma'ruf nahi munkar, sebagaimana penafsiran Hamka terhadap surah Luqman ayat 17 tersebut: inilah empat modal hidup yang diberikan Luqman kepada anaknya dan dibawakan menjadi modal pula bagi kita semua yang disampaikan oleh Muhammad kepada umatnya. Untuk memperkuat pribadi dan meneguhkan hubungan dengan Allah, untuk memperdalam rasa syukur kepadaNya atas nikmat dan perlindungan-Nya yang selalu kita terima, dirikanlah shalat. Dengan shalat, kita melatih lidah, hati dan seluruh anggota badan selalu ingat kepada Tuhan. Apabila telah kuat ibadah, maka lakukanlah tugas berikutnya yaitu berani menyuruh yang ma'ruf.

Maksudnya perbuatan baik yang diterima oleh masyarakat. Berusahalah jadi pelopor perbuatan baik. Orang yang telah kokoh pribadinya karena ibadah maka dia dituntut untuk berani menyampaikan kebenaran kepada sesama manusia, sekedar ilmu dan kesanggupan yang ada padanya. Sekurang-kurangnya menyuruh anak istri sembahyang. Sesudah itu, hendaklah berani pula menegur mana perbuatan yang munkar, yang tidak dapat diterima masyarakat. Berani mengatakan yang benar, meskipun pahit. Tentu saja kemudian pasti ada yang tidak senang dan marah karena ditegur, maka tetaplah bersabar. Ingatlah bahwa sekalian Rasul yang dikirim Allah dalam memberi bimbingan kepada manusia, semuanya disakiti oleh kaumnya. Modal utama mereka ialah sabar. ${ }^{43}$ Oleh sebab itu, sudah seharusnya manusia memiliki kesamaan untuk mendapatkan hak dalam hidup. Manusia dalam pergaulan hidup terdapat perbedaan-perbedaan golongan dan tingkat kehidupan, ada yang menjadi buruh ada

\footnotetext{
${ }^{40}$ Hamka, Falsafah Hidup, (Medan: Pustaka Islamiyah, 1980), h. 71.

${ }^{41}$ Hamka, Lembaga Hidup, (Jakarta: Djajamurni, 1972), h. 130.

${ }^{42}$ Hamka, Prinsip dan Kebjikasanaan Da'wah Islam, (Jakarta: Pustaka Panjimas, 1990), h.160.

${ }^{43}$ Hamka, Prinsip dan Kebjikasanaan Da'wah Islam, (Jakarta: Pustaka Panjimas, 1990), h.133
} 
majikan, ada bangsawan dan ada petani, namun semuanya diakui, mereka mempunyai hak dan kewajiban yang sama di muka hukum dan undang-undang. Perbedaan tingkat kehidupan didalam suatu masyarakat bukanlah berasal dari kehendak hukum dan undang-undang, tetapi hanyalah sebagai sebab perbedaan ilmu, dan nasib.

Adapun kemerdekaan adalah semangat hidup manusia dan tonggak kejayaannya. Manusia dilahirkan merdeka. Ia lahir ke dunia dengan tidak mengenal perbedaan. Oleh sebab itu, didalam kehidupannya manusia hendaknya tetap menjadi orang merdeka dan jangan sampai diikat oleh belenggu perbudakan dan tawanan. Berdasarkan ayat tersebut, menurut Hamka bahwa urgensi pendidikan adalah untuk membantu manusia memperoleh penghidupan yang layak, tetapi lebih dari itu, dengan ilmu manusia akan mampu mengenal tuhannya, memperhalus akhlaknya, dan senantiasa berupaya mencari keridhaan Allah. Sebab, tujuan pendidikan adalah untuk mengabdi dan beribadah kepada Allah. Oleh karena itu, dalam materi pendidikan harus mencakup tiga hal berikut: ilmu, amal, akhlak dan keadilan.

\section{KESIMPULAN}

Gambaran pelanggaran sosial yang terjadi di bangsa ini membuka ruang untuk merefleksikan sejauh mana usaha pendidikan formal yang merupakan lembaga teroganisir bangsa mendidik, mengarahkan dan membimbing peserta didik secara normatif. Karena menurut pandangan beliau bahwa pendidikan merupakan sarana mendidik watak pribadi. Pemikiran pendidikan Islam menurut Hamka adalah dimana bimbingan keagamaan orang tua terhadap anak yaitu: membantu manusia memperoleh penghidupan yang layak, tetapi lebih dari itu, dengan ilmu manusia akan mampu mengenal tuhannya, memperhalus akhlaknya, dan senantiasa berupaya mencari keridhaan Allah. Sebab, tujuan pendidikan adalah untuk mengabdi dan beribadah kepada Allah. Karena itu, dalam materi pendidikan harus mencakup tiga hal berikut: ilmu, amal, dan akhlak. Dapat dikatakan bahwa pendidikan Islam menurut Hamka, tentang pendidikan baik dari urgensinya, maknanya, materinya, dan tujuannya dapat dipahami bahwa pendidikan Islam adalah suatu usaha membimbing dan memberikan keilmuan bedasarkan ajaran agama Islam terhadap anak didik agar kelak setelah selesai pendidikannya dapat memahami dan mengamalkan agama Islam.

\section{DAFTAR PUSTAKA}

al-Abrāsyiy, Muhammad 'Athiyat. 1975. Al-Tarbiyat al-Islamiyat wa Falāsifatuhā. Mishr:'Īsā al-Bābiy al-Halabiy

al-Ahwani, Ahmad Fu`ad. 1967. Al-Tarbiyah fi al-Islam, Cetakan II. t.tp.: Dar al-Ma'arif al-Attas, Syed Muhammad Naquib. 1984. Konsep Pendidikan dalam Islam. Bandung: Mizan al-Qardhāwiy, Yūsuf. 1980. Al-Tarbiyat al-Islāmiyat wa Madrasat Hasan al-Banna. Penerjemah: H. Bustami A. Gani dan Ahmad, Zainal Abidin, Pendidikan Islam dan Madrasah Hasan al-Banna. Jakarta: Bulan Bintang

Arief, Armai. 2009. Reformulasi Pendidikan Islam. Jakarta: CRSD Press

Damami, Mohammad. 2000. Tasawuf Positif, (Dalam Pemikiran Hamka. Yogyakarta: Fajar Pustaka, Cet I 
Daradjat, Zakiah, dkk. 1983. Ilmu Pendidikan Islam. Jakarta: Proyek Pembinaan Perguruan Tinggi Agama/IAIN

Hamka. 1972. Lembaga Hidup. Jakarta: Djajamurni

1972. Doktrin Islam yang Menimbulkan Kemedekaan dan Keberanian. Jakarta: Yayasan Idatu . 1979. Kenang-kenangan Hidup. Jakarta: Bulan Bintang. Jilid I . 1980. Falsafah Hidup. Medan: Pustaka Islamiyah . 1982. Kenang-kenangan Hidup. Kuala Lumpur: Pustaka Antara. Jilid III, Cet II . 1083. Kenang-kenangan Hidup. Jakarta: Bulan Bintang. Jilid II . 1984. Pelajaran Agama Islam. Jakarta: Bulan Bintang. 